\title{
DISPLASIA FIBROSA DOS MAXILARES: RELATO DE UM CASO TRATADO CIRURGICAMENTE
}

Guilherme STRUJAK, André Luiz ZETOLA

As lesões fibro-ósseas dos maxilares representam um grupo de processos que são caracterizados por substituição do osso normal por tecido fibroso contendo um material mineralizado. Cientes disso, recebemos uma paciente, 19 anos, apresentando uma tumefação no ramo mandibular esquerdo. Na radiografia panorâmica uma lesão radiopaca, ocupava ramo, processo coronóide e corpo mandibular esquerdos. Foi optado pela ressecção cirúrgica. O tumor foi removido e o nervo mandibular foi ressecado, sendo realizada a enxertia utilizando o nervo sural. A cortical inferior da mandíbula foi preservada. A paciente foi mantida com bloqueio maxilo mandibular (BMM). No exame histopatológico foram encontradas células fusiformes e formações de tecido duro com aspecto de letras chinesas. O diagnóstico foi de displasia fibrosa. Aos 33 dias de pósoperatório foi aberto o BMM e a paciente relatou formigamento no lábio. Com 47 dias ocorreu a fratura na cortical residual sendo realizado BMM. Aos 59 dias foi retirado BMM a pedido da paciente sendo que foi notado leve deslocamento do bloco ósseo. Com 5 meses o bloco ósseo já havia consolidado. Aos nove meses a paciente relatou total sensibilidade do lábio inferior. Após 5 anos não há indicação de recidiva da lesão, e com sensibilidade normal do lábio inferior. 